The mechanisms underlying the

\title{
Lymphoma and other malignancies in primary Siögren's syndrome
}

\section{S R Pillemer}

\section{Low peripheral $C D 4+$ counts or low $C D 4+/ C D 8+$ ratios may be important risk factors for lymphoma in SS}

$\mathrm{T}$ heander et al break new ground with the observation that a low CD4+/CD8+ T lymphocyte ratio is a risk factor for the development of B cell lymphoma in Sjögren's syndrome (SS) in a longitudinal population based study. ${ }^{1}$ Also, while the incidence of lymphoma is substantially increased in their patients with SS over that in the general population, it is not as high that described in an initial report in a highly selected population. This increased risk of developing lymphoma was seen only in patients who met the American European classification criteria (AECC) for SS. ${ }^{2}$ Additionally, Theander et al found that purpura or skin vasculitis, and low C3 and low C4 are associated with the development of haematological malignancy. ${ }^{1}$ Interestingly, while indolent lymphomas (often of the mucosa associated lymphoid tissue (MALT) type) are more commonly reported in SS, Theander et al found that $58 \%$ in their cohort had high grade, diffuse large B cell lymphomas. ${ }^{1}$ A strength of their study is the use of the Swedish health registers to provide population based data and the availability of a well characterised population of patients with SS.

An intriguing, incidental, and tenuous observation, which will require further investigation, is that a history of skin cancer may increase the risk of later developing lymphoma in patients with SS. The interpretation of these findings is discussed here.

The findings of Theander et $a l^{1}$ regarding risk factors for B cell lymphomas in $\mathrm{SS}^{2}$ raise interesting questions.

\section{Why are patients with SS more prone to B cell lymphomas?}

In part, the answer relates to the clinical characteristics of the disease, and that lymphocytes, including $\mathrm{B}$ cells, are important in SS. SS has been described as an autoimmune exocrinopathy or epitheliitis. ${ }^{3}$ Lymphocytic infiltration of the glandular epithelial tissue is a major feature of SS, and results in benign lymphoepithelial lesions. ${ }^{4}$ Anatomically, B cell lymphomas in SS often arise in
MALT. ${ }^{5}$ This suggests that tissue inflammation in SS serves as a ground for the development of lymphoid malignancies. Although B lymphocytes are present, the majority of infiltrating lymphocytes in the exocrine tissue biopsy specimens and MALT from patients with SS are T cells, and these are mostly CD4+ cells. ${ }^{5}$ The microenvironment of $\mathrm{B}$ cells, including $\mathrm{T}$ cells, dendritic cells, cytokines, chemokines, and possibly, persistent antigens, is likely to have a role in the genesis of lymphoma.

\section{"The risk of developing lymphomas is increased 16-fold in patients with $\mathrm{SS}^{\prime \prime}$}

The likelihood of developing lymphoma also relates to the way in which SS is defined. Theander et al observed that the risk of developing lymphoma resided in those patients who met the AECC, not those who did not fulfil them. ${ }^{12}$ Earlier versions of the European classification criteria allowed for the possibility that a patient could fulfil the criteria without having objective evidence of autoantibodies and tissue infiltration. ${ }^{2}$ A patient with SS who has insufficient infiltration to meet the biopsy criterion might be less likely to have substantial lymphocytic infiltration elsewhere in the body and a smaller chance of developing lymphoma.

Of the rheumatic autoimmune diseases, SS is the one most strongly associated with B cell lymphomas. ${ }^{6}$ Theander et al found about a 16-fold increased risk of developing lymphoma in patients with SS. ${ }^{1}$ The initial report that patients with SS have up to a 44 times increased risk of developing lymphoma compared with the general population was based on a highly selected group of patients in a study that was not population based. ${ }^{7}$ Up to $10 \%$ of patients with SS may develop malignant lymphoma. ${ }^{18}$ In a multicentre European study, lymphoma occurred in $4.3 \%^{7}$ of patients with SS, mostly low grade B cell lymphoma of the MALT type. development of $\mathrm{B}$ cell lymphomas in SS potentially include defects in apoptosis, persistent antigenic stimulation, the mutagenicity of $\mathrm{B}$ cells, $\mathrm{T}$ cell modulation, and the effects of various molecules such as BLyS or type 1 interferons. ${ }^{569}$ Defective apoptosis may have a role by prolonging survival of $\mathrm{B}$ cells.

Prolonged inflammation in SS, together with persistent antigenic stimulation organisms such as Helicobacter pylori and human herpes virus (HHV) infection, may have a role in the development of lymphoma. ${ }^{1561011}$ Regression of MALT lymphoma after antibiotic treatment suggests that chronic antigenic stimulation by $H$ pylori may play a part in some MALT-type B cell lymphomas. ${ }^{5}$

Mutagenicity of $\mathrm{B}$ cells is another potential mechanism for lymphoma in SS. ${ }^{6}$ Immunoglobulin generation occurs early in the development of B cells in the bone marrow. During later developmental steps of B cells, immunoglobulins undergo recombination, somatic mutation, and isotype switching, which requires breaking and reconnecting DNA. These events increase the risk of translocation of oncogenes such as Bcl-2 and c-Myc to immunoglobulin loci. The resulting $\mathrm{B}$ cells may be resistant to apoptosis or may show enhanced proliferation, which would tend to favour the development of lymphoma. In mucosal sites and exocrine glands in SS the increased mass of benign $\mathrm{B}$ cells may itself result in an increased probability of mutations that could result in malignancy.

$T$ cells could enhance the tendency toward the development of lymphoma. $^{514}$ In SS, it is possible that regulatory $\mathrm{T}$ cells might inhibit protective polyclonal $\mathrm{T}$ cell lymphocytic infiltrates in mucosal and exocrine tissues, allowing clonal B lymphoid cells to escape immunological surveillance and elimination. ${ }^{14}$ On the other hand, T cells, through the production of BLyS or other promoters of B cell proliferation, may tip the balance towards lymphoma.

Patients with SS have increased levels of circulating BLyS (BAFF) and strong expression in lymphocytic infiltrates of the labial salivary gland biopsies. ${ }^{9}$ BLyS is a B cell activating factor, which regulates $B$ cell differentiation and proliferation, and has a role in the pathogenesis of both SS and $\mathrm{B}$ cell lymphomas.' Marginal zone B cells may form germinal centres in the salivary glands of some patients with SS, which could give rise to oligoclonal populations of B cells, possibly resulting in MALT lymphoma. ${ }^{15}$ 
Type 1 interferon signature has been reported in salivary glands and in peripheral blood of patients with SS. ${ }^{16}{ }^{17}$ A hypothesis about the role of type 1 interferons in SS has been suggested by Båve et al. ${ }^{16}$ Viral infections or other events may promote apoptosis of salivary epithelial cells, resulting in the release of RNA and RNA binding proteins, which include anti-Ro and anti-La. Antibodies develop against Ro and possibly other RNA binding proteins, resulting in immune complexes. Such complexes may attach to natural interferon-producing cells or plasmacytoid dendritic cells which have surface Fc $\gamma$ II receptors. The immune complexes may be internalised and interact with Toll-like receptor 7 , resulting in the production of type 1 interferons. Type 1 interferons also increase expression of BLyS, which in turn is postulated to have a role in B cell lymphoma.

Why are low CD4+ cell counts, low CD4+/CD8+ ratios, low C3 or C4 levels, and cutaneous vasculitis or purpura associated with an increased likelihood of developing lymphoma in patients with SS?

In SS salivary and lachrymal gland biopsies the predominant lymphocyte is $\mathrm{CD} 4+.{ }^{5}$ One can speculate that the traffic of $\mathrm{CD} 4+$ cells from the periphery into the tissues results in a decreasing number of circulating CD4+ and also a decrease in the CD4+/CD8+ ratio. The T cells persist and might result in chronic stimulation of B cells. B cell lymphomas tend to develop in such extranodal tissue sites. It would seem then that the low $\mathrm{CD} 4+$ or decrease in $\mathrm{CD} 4+/ \mathrm{CD} 8+$ may reflect the amassing of $\mathrm{T}$ cells in tissues to the extent that the risk of developing lymphoma substantially increases.

Can the association between low complement levels and the development of lymphoma in SS be explained? This association has been described in other studies of SS. ${ }^{8}{ }^{18}$ One may speculate that low complement levels could facilitate the survival of B cells. In systemic lupus erythematosus, evidence suggests that the survival of autoreactive B cells may be affected by various complement components. ${ }^{19}$ In healthy subjects, it seems that complement has a role in the negative selection of self reactive $B$ cells, resulting in apoptosis in bone marrow and the periphery. In the light of these considerations, the association between low C3, and possibly C4 levels, in SS might potentially have a role in the survival of autoreactive B cells. Prolonged survival of B cells could increase the risk that unfavourable mutations might occur, resulting in malignancy.
The relationship between vasculitis and malignancy might be explained by the association of prolonged inflammatory processes and vasculitis with low complement levels. In addition, in other studies, peripheral neuropathy, which tends in patients with SS to be a complication of vasculitis, is also associated with an increased risk of developing B cell lymphomas. ${ }^{8}$ The vasculitis in SS tends predominantly to affect the lower limbs and is generally leucocytoclastic vasculitis or palpable purpura, which is associated with cryoglobulins.

\section{Are more aggressive B cell lymphomas more common than previously thought?}

This remains to be seen. Although this finding is intriguing, the number of patients with lymphoma in the study by Theander et al is small. ${ }^{1}$ The multicentre European study, which had a greater number of patients with lymphoma did not show the excess of aggressive lymphomas reported by Theander et al. ${ }^{8}$ Across the world there are cohorts of patients with well characterised SS, from whom those with lymphoma could be selected. Extension of the European study to other countries such as Canada, the United States, Mexico, Japan, China, and others would provide a wealth of information on the spectrum of lymphomas in SS. Another consideration is that it is known that indolent lymphomas may transform into aggressive lymphomas over time. Length of follow up may be important in the spectrum of lymphomas. Possibly, also, the spectrum of lymphomas might vary geographically because of environmental differences, such as differences in prevailing micro-organisms, and genetic background.

\section{Does a history of cutaneous malignancy increase the risk of lymphoma in patients with SS?}

More studies will be necessary to answer this question. SS does not appear to be associated with a greater prevalence of cancers, other than B cell malignancies, than the general population. The presence of cutaneous cancer might still be a risk factor for the development of B cell malignancies. If data on skin cancers were to be collected in an international study such as that suggested above for lymphomas in patients with SS, this interesting question could be pursued.

\section{CONCLUSION}

The study of Theander et al brings to light a new interesting finding that low peripheral $\mathrm{CD} 4+$ counts or low CD4+/ CD8+ ratios may be important risk factors for lymphoma in patients with
SS. In addition, they confirm and extend observations on other known risk factors such as vasculitis or pupura and low serum complement levels. They have also described other observations worthy of further investigation, such as the observation that cutaneous malignancy may be a risk factor for the development of B cell lymphoma. Their observations suggest that there is still much to be learnt about the risk factors for the development of B cell malignancies in SS, and equally important, the mechanisms underlying risk factors, such as peripheral CD4+ cell depletion and low serum complement levels. The current state of knowledge presents us with opportunities to increase our understanding of this interface of autoimmunity and B cell malignancies, SS.

Ann Rheum Dis 2006;65:704-706.

doi: $10.1136 /$ ard.2005.044362

Correspondence to: Dr S R Pillemer, Clinical Development, Immunological and Inflammatory Diseases, Medlmmune, Inc, One Medimmune Way, Gaithersburg, Maryland 20878, USA; pillemers@medimmune.com

Accepted 16 February 2006

Competing interests: None.

\section{REFERENCES}

1 Theander E, Henriksson G, Liungberg O, Mandl T, Manthorpe R, Jacobsson LTH. Lymphoma and other malignancies in primary Siögren's syndrome: a cohort study on cancer incidence and lymphoma predictors. Ann Rheum Dis 2006:65:796-803.

2 Vitali C, Bombardieri S, Jonsson R, Moutsopoulos HM, Alexander EL, Carsons SE, et al. Classification criteria for Sjögren's syndrome: a revised version of the European criteria proposed by the American-European Consensus Group. Ann Rheum Dis 2002;61:554-8.

3 Jonsson R, Moen K, Vestrheim D, Szodoray P. Current issues in Siögren's syndrome. Oral Dis 2002;8:130-40.

4 Harris NL. Lymphoid proliferations of the salivary glands. Am J Clin Pathol 1999;111(suppl 1):S94-103.

5 Masaki Y, Sugai S. Lymphoproliferative disorders in Sjögren's syndrome. Autoimmun Rev 2004;3:175-82

6 Mackay IR, Rose NR. Autoimmunity and lymphoma: tribulations of B cells. Nat Immunol $2001 ; 2: 793-5$.

7 Kassan SS, Thomas TL, Moutsopoulos HM, Hoover R, Kimberly RP, Budman DR, et al. Increased risk of lymphoma in sicca syndrome. Ann Intern Med 1978:89:888-92.

8 Voulgarelis M, Dafni UG, Isenberg DA, Moutsopoulos HM. Malignant lymphoma in primary Siögren's syndrome. Arthritis Rheum 1999:42: 1765-72

9 Groom J, Kalled SL, Cutler AH, Olson C Woodcock SA, Schneider P, et al. Association of BAFF/BLyS over expression and altered B cell differentiation with Siögren's syndrome. J Clin Invest 2002;109:17-18.

10 Nishimura M, Miyajima S, Okada N. Salivary gland MALT lymphoma associated with Helicobacter pylori infection in a patient with Sjögren's syndrome. J Dermatol 2000;27:450-2.

11 Klussmann JP, Wagner M, Guntinas-Lichius O, Muller A. Detection of HHV-8 sequences and antigens in a MALT lymphoma associated with Sjögren's syndrome. J Oral Pathol Med 2003:32:243-5. 
12 Savio A, Franzin G, Wotherspoon AC, Zamboni $G$, Negrini R, Buffoli $F$, et al. Diagnosis and posttreatment follow-up of Helicobacter pylori-positive gastric lymphoma of mucosaassociated lymphoid tissue: histology, polymerase chain reaction, or both? Blood 1996:87:1255-60.

13 Theander E, Nilsson I, Manthorpe R Jacobsson LT, Wadstrom T. Seroprevalence of Helicobacter pylori in primary Sjögren's syndrome. Clin Exp Rheumatol 2001;19:633-8.

14 Gottenberg JE, Lavie F, Abbed K, Gasnault J, Le Nevot E, Delfraissy JF, et al. CD4 CD25 high regulatory $T$ cells are not impaired in patients with primary Sjögren's syndrome. J Autoimmun 2005:24:235-42.

15 Szodoray $\mathbf{P}$, Jellestad S, Teague MO, Jonsson R. Attenuated apoptosis of $B$ cell activating factorexpressing cells in primary Sjögren's syndrome. Lab Invest 2003:83:357-65.

16 Båve U, Nordmark G, Lovgren T, Ronnelid J, Cajander S, Eloranta ML, et al. Activation of the type I interferon system in primary Sjögren's syndrome: a possible etiopathogenic mechanism. Arthritis Rheum 2005;52:1185-95.
17 Hielmervik TO, Petersen K, Jonassen I, Jonsson R, Bolstad Al. Gene expression profiling of minor salivary glands clearly distinguishes primary Sjögren's syndrome patients from healthy control subjects. Arthritis Rheum 2005; 52: 1534-44

18 loannidis JP, Vassiliou VA, Moutsopoulos HM Long-term risk of mortality and lymphoproliferative disease and predictive classification of primary Sjögren's syndrome. Arthritis Rheum 2002;46:741-7.

19 Carroll MC. The complement system in B cell regulation. Mol Immunol 2004;41:141-6.

\section{Clinical Evidence-Call for contributors}

Clinical Evidence is a regularly updated evidence-based journal available worldwide both as a paper version and on the internet. Clinical Evidence needs to recruit a number of new contributors. Contributors are healthcare professionals or epidemiologists with experience in evidence-based medicine and the ability to write in a concise and structured way.

Areas for which we are currently seeking contributors:

- Pregnancy and childbirth

- Endocrine disorders

- Palliative care

- Tropical diseases

We are also looking for contributors for existing topics. For full details on what these topics are please visit www.clinicalevidence.com/ceweb/contribute/index.jsp

However, we are always looking for others, so do not let this list discourage you.

Being a contributor involves:

- Selecting from a validated, screened search (performed by in-house Information Specialists) epidemiologically sound studies for inclusion.

- Documenting your decisions about which studies to include on an inclusion and exclusion form, which we keep on file.

- Writing the text to a highly structured template (about 1500-3000 words), using evidence from the final studies chosen, within 8-10 weeks of receiving the literature search.

- Working with Clinical Evidence editors to ensure that the final text meets epidemiological and style standards.

- Updating the text every 12 months using any new, sound evidence that becomes available. The Clinical Evidence in-house team will conduct the searches for contributors; your task is simply to filter out high quality studies and incorporate them in the existing text.

If you would like to become a contributor for Clinical Evidence or require more information about what this involves please send your contact details and a copy of your CV, clearly stating the clinical area you are interested in, to CECommissioning@bmigroup.com.

\section{Call for peer reviewers}

Clinical Evidence also needs to recruit a number of new peer reviewers specifically with an interest in the clinical areas stated above, and also others related to general practice. Peer reviewers are healthcare professionals or epidemiologists with experience in evidence-based medicine. As a peer reviewer you would be asked for your views on the clinical relevance, validity, and accessibility of specific topics within the journal, and their usefulness to the intended audience (international generalists and healthcare professionals, possibly with limited statistical knowledge). Topics are usually 1500-3000 words in length and we would ask you to review between 2-5 topics per year. The peer review process takes place throughout the year, and out turnaround time for each review is ideally 10-14 days.

If you are interested in becoming a peer reviewer for Clinical Evidence, please complete the peer review questionnaire at www. clinicalevidence.com/ceweb/contribute/peerreviewer.jsp 